Revista do Corpo Discente do Programa de Pós-Graduação em História da UnB EM TEMPO DE HISTÓRIAS | Brasília-DF | n. 37 | p. 473-493 | jul./dez. 2020.

\title{
DOSSTÊ
}

\section{O minimalismo absurdo na animação Morte e Vida Severina de Afonso Serpa}

\author{
The absurd minimalism in the animation \\ Death and Life of a Severino by Afonso Serpa
}

\author{
Daniel Ferreira da Silva \\ Doutorando em Línguas Românicas na Universidade da Geórgia \\ orcid.org/0000-0003-3031-3959 \\ danielfs@uga.edu
}

\begin{abstract}
RESUMO: Este trabalho analisa a estética minimalista do Teatro do Absurdo empregada para transformar a peça-poema Morte e Vida Severina em animação cinematográfica 3D. Nesse sentido, analisa-se a produção de uma mise-en-scène marcada, audiovisualmente, por um existencialismo essencial e universal. O enfoque esteve em elementos sonoros e cores monocromáticas que universalizam o sertão através do sentimento de espanto, da sensação de silêncio e vazio e de uma monotonia existencial. A partir dessas percepções mais universais, discutimos como a estética minimalista universal, oriunda do Teatro do Absurdo, se atualiza no cartunismo xilográfico de Serpa. Analisamos ainda como essa técnica, oriunda do Nordeste brasileiro, ajuda a retratar a complexidade e a sofisticação da tragédia humana, em um mundo pós-conflito. A tragédia humana, por sua vez, se atualiza em diferentes eventos históricos, épocas e sociedades. Neste trabalho, vemos o sertanejo Severino se tornar um homem universal, vivenciando no sertão a sua trágica versão de um mundo absurdo.
\end{abstract}

PALAVRAS-CHAVE: Universalismo. Minimalismo. Sina sertaneja.

ABSTRACT: This work analyzes the minimalist aesthetic of Theater of the Absurd applied to the adaptation of the poetic narrative Death and Life of a Severino into a cinematographic $3 \mathrm{D}$ animation. The focus was the essentiality of a universal existentialism that shaped the mise-en-scène. I analyzed the universalization of the sertão through blaring sound effects and monochromatic colors. These elements generated feelings of astonishment, emptiness, and deafening silence, impressions that are universally acknowledged. Subsequently, I described Serpa's cinematography and his use of a universal minimalism in combination with a woodcut cartoonism that is unique to the Brazilian Northeast. I also described the complexity and sophistication of Serpa's representation of the human tragedy staged in a post-conflict world. And, ultimately, I analyzed the tragic fate of the sertanejo man Severino, whose life's nemesis exceeded the limits of the sertão to become part of a world of absurdity.

KEYWORDS: Universalism. Minimalism. Sertanejo's fate. 
Revista do Corpo Discente do Programa de Pós-Graduação em História da UnB EM TEMPO DE HISTÓRIAS | Brasília-DF | n. 37 | p. 473-493 | jul./dez. 2020.

ISSN 2316-1191

\section{Introdução}

Em 2012, o diretor Afonso Serpa e o cartunista Miguel Falcão trouxeram para o mundo da animação cinematográfica 3D uma representação inovadora da peça-poema Morte e Vida Severina (1955), do poeta pernambucano João Cabral de Melo Neto. Afonso Serpa, enquanto diretor, recria a carga poética da peça-poema evidenciando, na animação, significados sintetizados por Falcão na sua arte monocromática que mistura cartunismo e xilogravura. Além disso, o foco narrativo muda do flagelo físico do sertanejo para temáticas mais psicológicas que conectam o teatro representativo do sertão ao teatro mais universal.

A animação Morte e Vida Severina se torna mais universal, por exemplo, ao assumir uma estética como a do Teatro do Absurdo, movimento que dá ênfase à tragédia humana. Tal associação é possível com base no que defende Luiz Camilo Lafalce no artigo "Breve Comentário sobre o Teatro do Absurdo" (2011). Nesse artigo, Lafalce fala do Teatro que se universalizou no século XX por seu aspecto estilístico que buscava revelar o "feio" e o nefasto da condição humana. Segundo Lafalce, o Teatro do absurdo retoma uma ideia de Albert Camus que, em 1941/1942, em plena Segunda Guerra Mundial, publicou $O$ mito de Sísifo. Esse ensaio, de acordo com Lafalce, "se debruça sobre o conhecido mito grego, procurando interpretá-lo à luz dos novos tempos: tempos de atrocidades institucionalizadas, de poder nefasto, de niilismo, de náuseas... tempos em que os ideais humanistas se traduziam em ideais existencialistas" (1). Trata-se, então, de um existencialismo resultante de um universo em que o homem é repentinamente privado de ilusões. Assim, Lafalce conclui que o mundo se torna um lugar estranho, marcado pelo divórcio entre o homem e a vida, restando-lhe o ceticismo e a morte.

Do universo descrito por Lafalce, surge o sentimento de espanto que passa a ser a assinatura universal da estética do Teatro do Absurdo. Essa estética da desesperança parece encontrar inspiração nos conflitos internos do homem moderno. Esses conflitos ganham novas roupagens no contínuo da tragédia humana que nunca cessa, mas apenas se atualiza através de sucessivos eventos históricos em diferentes sociedades. Esse é o caso da adaptação da peça-poema Morte e Vida Severina feita por Serpa. A adaptação recupera justamente a estética e o cenário de vazio físico e existencial do Teatro do Absurdo. Nela, de forma objetiva, Serpa tenta cristalizar na percepção e na memória um mundo que se reconhece como absurdo. Para ele, esse mundo é o sertão, lugar em que a existência humana se torna insípida e ilógica. E, é nesse mundo que conhecemos Severino, preso em uma situação sem solução, a seca cíclica do sertão. Em meio a uma natureza morta, que faz de sua vida uma jornada extenuante, Severino vê sua luta pela sobrevivência se transformar em um paradoxo absurdo e universal sobre a continuidade da vida.

Serpa reforça o lado universal de Morte e Vida Severina ao transportar esse universo de conflitos humanos para a realidade da animação 3D. Nessa modalidade audiovisual, ele investe nos traços monocromáticos do cartunismo e no essencialismo da xilogravura nordestina. Ele escolhe, assim, duas técnicas que criam uma linha tênue e 
Revista do Corpo Discente do Programa de Pós-Graduação em História da UnB EM TEMPO DE HISTÓRIAS | Brasília-DF | n. 37 | p. 473-493 | jul./dez. 2020.

ISSN 2316-1191

porosa que permite que conflitos existenciais fluam do regional para o universal e viceversa. Com essas técnicas, Serpa transforma o sertão físico em um espaço psicológico e consegue simplificar, traduzir e universalizar a percepção da realidade da seca do Nordeste brasileiro. De uma maneira geral, na seção de análise, buscamos verificar como a proposta de uma cinematografia minimalista de Serpa ajudou na universalização dos temas presentes, originalmente, na peça-poema de Melo-Neto. Depois, buscamos entender como Serpa construiu, audiovisualmente, tal minimalismo universal no sertão abstrato de Morte e Vida Severina.

No centro da análise do minimalismo na obra de Serpa, estiveram as cores neutras e absolutas preto e branco e a repetição de imagens com traços abstratos. Esses elementos se somam a uma sonorização aguda para preencher o sertão com um universalismo multisensorial. Neste sentido, o sertão parece se comunicar diretamente com o espectador por meio de técnicas audiovisuais minimalistas. Nessas técnicas, os elementos minimalistas de ambientação (i.e. cores e sons) ganham valor próprio no universo da animação e, por isso, foram analisados. Eles compõem um vocabulário multisensorial que Serpa utilizou para reproduzir, por exemplo, a ausência de estímulos externos em um mundo dominado por um niilismo fúnebre e por um vazio existencial. Estes dois últimos parecem impregnar o psicológico de Severino com o sentimento de espanto, a sensação de silêncio e vazio, a monotonia e a repetição de imagens (i.e. vocabulário pictorial). Assim, vemos Severino se tornar um "homem universal," que vive em um mundo pós-conflito/pós-tragédia. Esse mundo é o sertão monocromático da animação Morte e Vida Severina.

Além disso, foi interessante observar também como a estética cinematográfica e os objetivos de Serpa com a animação se relacionam com o Cinema do Terceiro Mundo, um movimento cinematográfico com traços de realismo social e engajamento político, como no caso do Cinema Novo. Tanto o realismo social quanto o engajamento político, que são característicos de temáticas sobre o sertão, se tornam "palimpsestos" cinematográficos e passam a acomodar temas mais metafísicos e filosóficos, ainda que permaneçam resquícios de realidade. Destaca-se, principalmente, o poder que a combinação entre o Cinema Novo e o cartunismo monocromático tem de universalizar o realismo social, fazendo-o circular também fora da esfera nacional brasileira. Por fim, a seguir, discutimos os traços regionais e universais que fazem com que Morte e Vida Severina tenha a crítica social do Cinema Novo, o regionalismo marcante da xilogravura, o essencialismo do cartunismo e a estética universal do Teatro do Absurdo.

\section{O universalismo cinematográfico da animação preto e branco}

No contexto nacional brasileiro, podemos relacionar a Animação com a Estética do Cinema Novo. Trata-se de uma estética influenciada pelo movimento neo-realista italiano, que, segundo a descrição de Susan Hayward, no livro Cinema Studies: The Key Concepts (2000), “...renovou uma estética cinematográfica apropriada ao Brasil contemporâneo onde a pobreza, a fome e a violência eram a dieta diária da maioria, e a 
Revista do Corpo Discente do Programa de Pós-Graduação em História da UnB EM TEMPO DE HISTÓRIAS | Brasília-DF | n. 37 | p. 473-493 | jul./dez. 2020.

ISSN 2316-1191

riqueza concentrada a boa fortuna de poucos"1 (HAYWARD, 2000, p. 56). A autora lembra que os nomes de Glauber Rocha, Nelson Pereira dos Santos e Rui Guerra revolucionaram a sétima arte no Brasil com a proposta do Cinema Novo de manifestações cinematográficas mais populistas e direcionado para fora dos grandes centros de cultura no Brasil dos anos de 1960. Como afirmou ainda Hayward, o então novo jeito de fazer Cinema era populista por misturar história, mito e cultura popular; e era revolucionário por focar na realidade marginal de brasileiros como os sertanejos sem-terras, uma realidade sem apelo mercadológico no Brasil, que, por sua vez, não estava imune à febre Hollywoodiana que acometia o mundo. Nascia, assim, o Cinema propositadamente subdesenvolvido, o Third World Cinema que explorava uma estética da fome e da violência e fazia disso uma alegoria do subdesenvolvimento. Parte dessa estética colocava a realidade agressiva do sertão para contrastar com o Cinema mundial e a máquina de fantásticos de Hollywood.

A relação com o Cinema Novo, todavia, não dá conta de explicar os avanços cinematográficos da animação cartunista Morte e Vida Severina. A mise-en-scéne da animação é constituída por elementos que só podem ser atenuados e percebidos em uma obra de consciência minimalista latente, ou seja, em que os traços mais essenciais de uma realidade, física ou psicológica, estão, nitidamente, evidenciados em imagens. São elementos que de outra forma passariam despercebidos: o espanto, o silêncio, o vazio, as cores monocromáticas, o espaço psicológico, a universalização do nome Severino e a repetição de imagens. O trabalho audiovisual feito com esses elementos garante, à animação, sua autenticidade e seu valor artístico próprio. Como destacou Jingfang Yu sobre a tradução semiótica em "Da palavra à imagem: Morte e Vida Severina em animação": “... o trabalho do cineasta parte de seu entendimento do texto literário, transcriando-o através da linguagem visual, assim, apresentando-nos sua interpretação do poema" (YU, 2010, p. 31). Estamos, desse modo, lidando com uma narrativa histórica que constitui a peça-poema de Melo-Neto, mas que é recuperada por meios semióticos cinematográficos distintos, resultando em um objeto estético autônomo: uma animação xilográfica e cartunista, tradicional e moderna, minimalista e universal.

Dentro dessa proposta, o cartunismo tem um papel fundamental na estética minimalista universal da animação. No capítulo 2, do livro Understanding Comics: The invisible Art (1993), Scott McCloud descreve as artes visuais a partir da perspectiva de quem observa e não da arte observada. Segundo o autor, "todos nós percebemos o mundo como um todo por meio da experiência de nossos sentidos. No entanto, nosso sentido só pode perceber um mundo que está fragmentado e incompleto"2 (MCCLOUD, 1993, p. 62). Desse modo, a nossa percepção simplifica o mundo e suas formas para melhor compreendê-los e, talvez, ignore o que não pode ser simplificado. Assim sendo,

\footnotetext{
${ }^{1}$ Tradução nossa. O original diz: “...renovate(d) a film aesthetic appropriate to contemporary Brazil where poverty, starvation and violence were the daily diet of most, and concentrated wealth the good fortune of the very few" (HAYWARD, 2000, p. 56)

2 Tradução nossa. O original diz: "All of us perceive the world as a whole through the experience of our senses. Yet our sense can only perceive a world that is fragmented and incomplete" (MCCLOUD, 1993, $p$. $62)$.
} 


\section{Fistororias}

Revista do Corpo Discente do Programa de Pós-Graduação em História da UnB EM TEMPO DE HISTÓRIAS | Brasília-DF | n. 37 | p. 473-493 | jul./dez. 2020.

ISSN 2316-1191

simplificar uma imagem é então uma forma de torná-la abstrata, retirá-la de sua realidade e amplificar (universalizar) seu sentido para melhor entendê-la. Nesse sentido, empresta-se de determinada realidade (imagem) o que ela tem de mais icônico e ao mesmo tempo relacionável e instigante.

A percepção do "todo" quando na verdade nos focamos apenas em partes, ocorre por meio de associação e preenchimento de lacunas que se dão por meio de projeções de autoimagem. Isso quer dizer que insumos visuais levam o espectador a se projetar no personagem/na cena, preenchendo as lacunas da narrativa com informações autoreferenciais. A esse fenômeno de observar partes e enxergar um todo, McCloud chama, no capítulo 3 do seu livro, de "desfecho" ou "closure", ou seja, simplificar o significante para amplificar o significado. Ele completa seu raciocínio dizendo que, às vezes, uma mera forma ou contorno é suficiente para desencadear o processo de desfecho no nosso cérebro. Em outras palavras, é mais fácil para nosso cérebro adicionar informação a uma cena de animação do que retirar dela informações que já estejam lá e que podem, eventualmente, diferenciar/distanciar o personagem do telespectador. Segundo McCloud, estamos nos movendo em uma linha pictorial que deixa para trás uma imagem realista, que é sempre mais local e situada, e avança em direção a uma imagem mais universal. Assim, a justaposição de um círculo, dois traços superiores menores e um traço inferior maior se torna a composição universal de um rosto.

O primeiro passo da universalização de uma narrativa parece ser a abstração de sujeitos, de personagens. O segundo passo é a abstração do meio, do plano de fundo da narrativa. A seguir, vemos, primeiramente, o processo de universalização do personagem por meio da Figura 01.

Figura 01: Esquema Pictorial das Artes Visuais

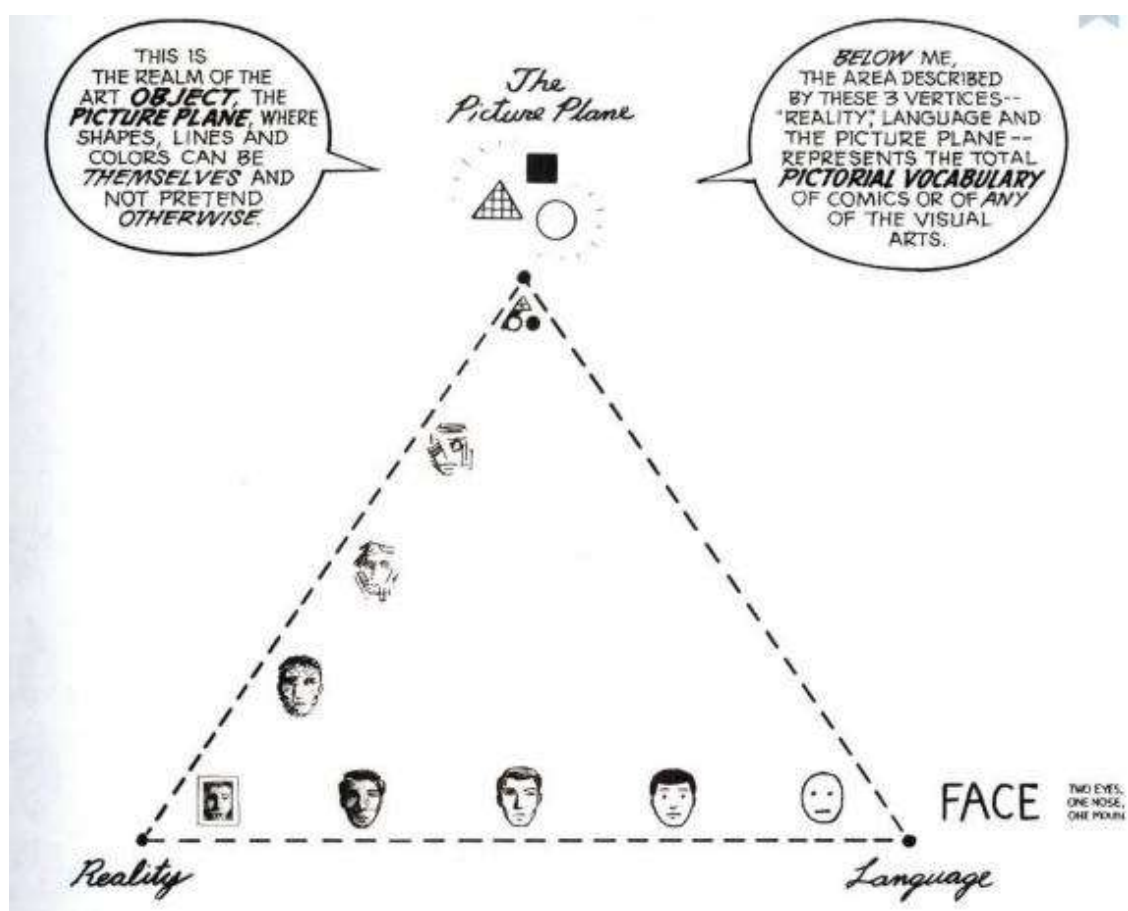

Fonte: Retirado de McCloud (1993, p. 51) 
Revista do Corpo Discente do Programa de Pós-Graduação em História da UnB EM TEMPO DE HISTÓRIAS | Brasília-DF | n. 37 | p. 473-493 | jul./dez. 2020.

ISSN 2316-1191

No esquema de universalização proposto por McCloud na Figura 01, há dois grupos de "visual planes" ou, em português, "planos visuais". O primeiro plano, descrito no primeiro balão como sendo "o plano de figuras em que formas, linhas e cores podem ser elas mesma"3 (MCCLAOUD, 1993, p. 51), é o que acomoda as formas básicas como o quadrado, triângulo e círculo, consideradas formas sem significado subjetivo. Já no segundo plano visual, referido no segundo balão, McCloud descreve "a área descrita por 3 vértices, realidade, linguagem, e plano das formas básicas, cuja a soma total forma um vocabulário pictorial"“ (MCCLAOUD, 1993, p. 51). Esse vocabulário pictorial, por sua vez, poderá ter significação culturalmente mais específica ou ter uma iconicidade mais universal, como mostra a sequência de representações do rosto humano no esquema elaborado por McCloud.

Ao adotar técnicas cartunistas, como a exemplificada por McCloud, Serpa extrai a essência da imagem do sertanejo, uma figura regional, transformando-o em um Severino, uma personagem construída com traços e expressividade mais universalmente reconhecíveis. A imagem de Severino é pensada como um canal de comunicação visual com o público. Por meio desse canal, se estabelece um processo de catarse da crise existencial sertaneja. Como resultado, o existencialismo do homem sertanejo ultrapassa os limites do sertão e invade o espaço universal.

Como veremos a seguir, o sertanejo aparece representado, na animação, com traços apenas suficientes para provocar o telespectador a fazer o "desfecho", isto é, projetar sua autoimagem no personagem e, de repente, assumir para si a realidade que era do outro. Há dessa forma um processo que mistura catarse e empatia em Morte Vida Severina. Tal processo é construído sobre "o jogo universal das máscaras": alegria, tristeza, e espanto, que são as expressões básicas do Teatro/Cinema mundial. Dessas, a máscara do "espanto", que representa a face do homem diante do desconhecido, é a menos conhecida. Mas, é essa máscara que Serpa usa para universalizar Severino, dando-lhe um rosto mundialmente reconhecível. Cria-se, assim, uma representação pictorial que é capaz de trazer à tona o que há de mais universal na realidade do homem sertanejo, seu existencialismo.

Inspirada na realidade sertaneja, Morte e Vida Severina apresenta uma personagem cuja marca universal é a expressão de espanto. Isto é dizer que, do lado direito da pirâmide esquemática de McCloud, teríamos o sertenejo que existe efetivamente e do lado esquerdo teríamos sua representação (ou abstração) gráfica. Essa representação gráfica do espanto, que se efetiva no rosto de Severino, enquanto homem universal, poderia está no centro da pirâmide, já que representa um equilíbrio entre a realidade e o plano pictorial, planos que estavam, anteriormente, sobrepostos pela linguagem da peça-poema, mas que agora encontram-se revelados. Também, dependendo do espectador (i.e. local ou universal), a face de Severino poderia gravitar

\footnotetext{
${ }^{3}$ Tradução nossa. O original diz: “...the picture plane, where shapes, lines and colors can be themselves..." (MCCLOUD, 1993, p. 51)

${ }^{4}$ Tradução nossa. O original diz: “... the area described by these 3 vertices - "reality", language and the picture plane - represents the total pictorial vocabulary...” (MCCLOUD,1993, p. 51).
} 


\section{Fistortorias}

Revista do Corpo Discente do Programa de Pós-Graduação em História da UnB EM TEMPO DE HISTÓRIAS | Brasília-DF | n. 37 | p. 473-493 | jul./dez. 2020.

ISSN 2316-1191

entre os três vértices, tocando pontos mais reais ou mais abstratos da pirâmide. Deixaríamos, assim, de analisar, por exemplo, a fotografia com traços pessoais e culturais mais marcados e passaríamos a analisar os traços mais universais do ser humano. Ainda assim, esta análise mais universal não estaria totalmente livre das reminiscências culturais, pois o rosto de espanto ainda se associa, no plano da linguagem, ao nome Severino, que é autenticamente sertanejo. Todavia, tais reminiscências culturais, com base no esquema de McCloud, não anulariam a projeção do homem sertanejo como um ícone universal. Como comprova a animação de Morte $e$ Vida Severina, ao contar a história de uma personagem sertaneja, conta-se também a história daqueles que se reconhecem nela, na sua efemeridade, ceticismo e desventuras. Nesse sentido, a tragédia humana se torna um contínuo de autoprojeções universais e locais que dialogam e dão significado à animação.

Nessa mesma linha, o cenário também pode ser um molde cinematográfico capaz de envolver o espectador na feitura do existencialismo universal em que ele e Severino se inserem conjuntamente. Para tal, é necessário que haja o mínimo de informação possível na cena. O objetivo é que o espectador não receba uma narrativa pronta, mas apenas estímulo suficiente, para se engajar na construção de uma narrativa em termos mais universais. Busca-se, assim, que o espectador preencha os espaços narrativos deixados propositadamente em branco com sua própria autoimagem em relação ao que seria sua versão de um universo absurdo, um mundo desconhecido. Esse poder sugestivo e envolvente da narrativa está representado logo abaixo, em um dos quadrinhos explicativos de McCloud, como podemos ver na Figura 02:

Figura 02: O Minimalismo Visual e a Universalização do Significado
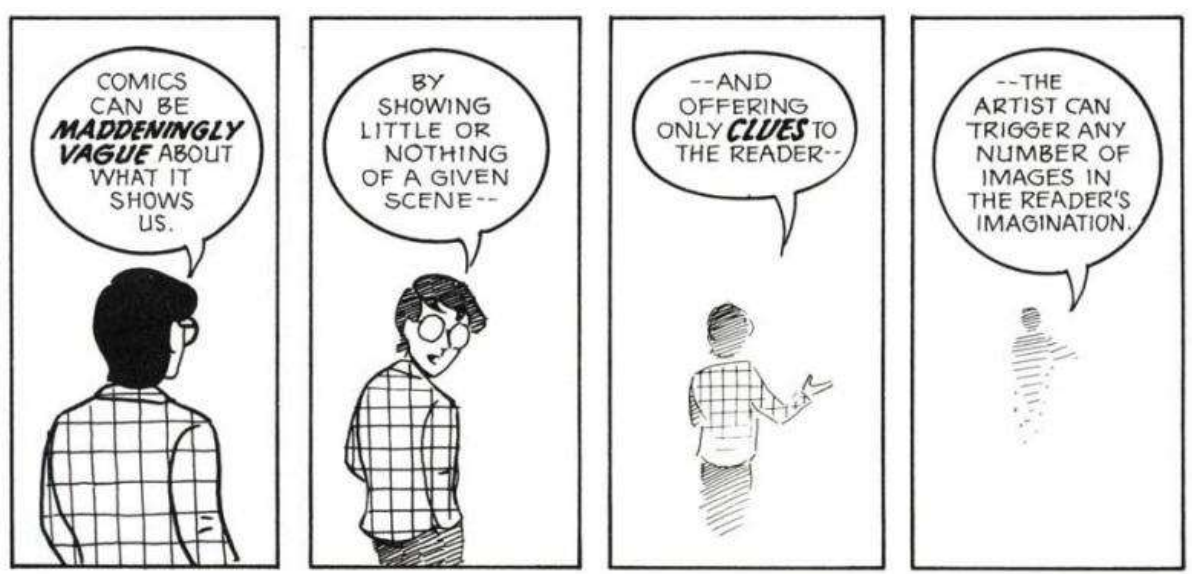

Fonte: Retirado de McCloud (1993, p. 86)

Como afirma McCloud na Figura 02, as artes visuais exemplificada por ele através do cartunismo e, por nós, através da animação 3D, "podem ser intencionalmente vagas sobre aquilo que mostram, mostrando pouco ou nada de uma dada cena, 
Revista do Corpo Discente do Programa de Pós-Graduação em História da UnB EM TEMPO DE HISTÓRIAS | Brasília-DF | n. 37 | p. 473-493 | jul./dez. 2020.

oferecendo apenas pistas ao leitor"5 (MCCLOUD, 1993, p.86). E, no último quadrinho da sequência que ilustra a discussão promovida por McCloud, ele afirma que o artista, através desse processo, "pode fazer surgir um grande número de imagens na imaginação do leitor"6 (p. 86). No caso da sequência de imagens acima, há o transporte do leitor de uma "realidade" mais concreta visualmente para uma realidade mais abstrata e fragmentada. A Figura 02 acima, por exemplo, pode ser interpretada como a transição de um plano concreto até um plano psicológico, mais abstrato e até mesmo sobrenatural.

Essa técnica adquire importância logo nos primeiros minutos da animação Morte e Vida Severina, como veremos, com mais detalhes, a seguir. Severino parece surgir de um plano abstrato e se materializa em uma realidade ficcional mais perceptível. A técnica é a mesma, mas, enquanto McCloud se move do concreto ao abstrato, Serpa traz o abstrato para o concretamente visual. A partir da aparição de Severino, os detalhes (traços e formas) na cor preta vão ocupando cada vez mais espaço na tela e, quando alcançam o limite, a tela escurece totalmente ao final. Serpa se utiliza da cor branca para dissipar a realidade criada e fazer com que, inesperadamente, o espectador retorne ao começo da narrativa com a impressão de que Severino surge do além, de uma espécie de mundo espiritual, representado pelo clarão que toma conta da tela nos primeiros segundos, antes mesmo do aparecimento de Severino; ou seja, no marco zero da narrativa, onde começa, a seguir, a nossa análise.

\section{A Estética de Morte e Vida Severina: do local ao universal}

Para entender a universalização no contexto cinematográfico de Morte e Vida Severina, temos que, primeiramente, entender que no cartunismo monocromático, o branco e o preto são cenários com significados. O grau de universalização cinematográfica e a densidade da arte visual são inversamente proporcionais, o que resulta em uma estética minimalista. A animação oferece só o necessário para aportar a experiência do telespectador. Ainda que nem todo telespectador esteja familiarizado com o sertão físico, é sabido que todos conhecem a sensação de "deserto", de "miragem", de encandeamento que são impressões acústicas relacionadas ao "vazio". Por sua vez, o "vazio" pode se traduzir, metafórica e cinematograficamente, em existencialismo, que, por seu lado, é uma temática universal. Dessa forma, a técnica acima anula qualquer espaço conhecido e o transforma em um espaço mental a ser preenchido pelo existencialismo de cada espectador, a partir das mais diversas experiências em (um) mundo(s) absurdo(s).

Enquanto a peça-poema é construída em cima do êxodo rural motivado pela seca que se agravou no Nordeste brasileiro em 1919/1920, a animação externaliza o mundo psicológico do sertanejo afetado pela natureza morta que o cerca. Por seu turno, o sertanejo é a representação de uma realidade hostil que é estampada no rosto de

\footnotetext{
${ }^{5}$ Tradução nossa. O original diz: “...can be maddeningly vague about what it shows us. By showing or nothing of a given scene and offering only clues to the reader..." (MCCLOUD, 1993, p.86).

${ }^{6}$ Tradução nossa. O original diz: "[In so doing] the artist can trigger any number of images in the reader's imagination" (MCLOUD, 1993, p.86).
} 


\section{Fistorias}

Revista do Corpo Discente do Programa de Pós-Graduação em História da UnB EM TEMPO DE HISTÓRIAS | Brasília-DF | n. 37 | p. 473-493 | jul./dez. 2020.

ISSN 2316-1191

Severino, bem como das demais personagens, cuja expressão facial é símbolo universal do espanto. Essa expressão é motivada pela seca eminente e pela morte que espreita. Certamente, a seca é uma realidade local, mas o espanto diante de um mundo que se torna abruptamente nocivo e absurdo é um sentimento universal. E, é justamente explorando a morte como estética visual e o espanto como tom narrativo que Serpa começa a sua animação. São esses os elementos que ele usa para criar um conhecimento compartilhado, uma base comum, para o público. A partir disso, busca-se produzir empatia entre o espectador e o personagem sertanejo Severino. Vejamos como isso se constrói de forma sequenciada no começo da animação por meio da Figura 03:

Figura 03: Ato I - O Retirante Explica ao Leitor Quem É e a Que Vai

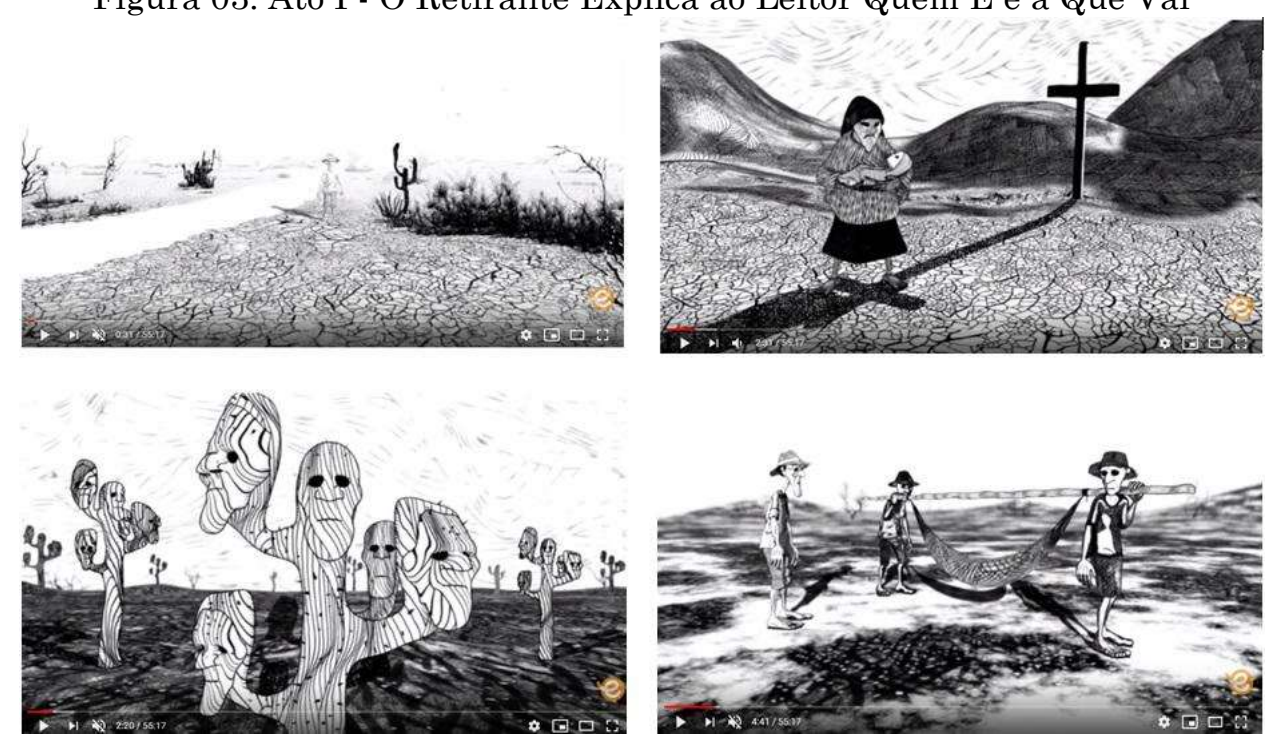

Fonte: Retirado de Serpa (2012, m. 1 e seg.)

Severino aparece nos primeiros minutos de abertura, entre os minutos 1 e 2 da animação, materializando-se aos poucos, como se fosse, inicialmente, uma miragem ou uma alma errante que vai se definindo na mise-en-scéne. Em seguida, na primeira aparição de Severino, já entendemos que se trata de uma narrativa universal, pois como antecipa os rostos similares das personagens, essas cenas sintetizam a ideia das primeiras estrofes da peça-poema: “- O meu nome é Severino/ há muitos Severinos/com mães chamadas Maria” (MELO-NETO, 1955, p. 02). Depois, na segunda cena, entendemos que Severino também tem uma origem mítica, pois é nascido da morte, de um pai morto, chamado Zacarias. Na terceira cena, a natureza que cerca Severino reflete seu rosto, um rosto cansado de tentar resistir à morte em um meio veementemente hostil. Na quarta cena, vemos que Severino não está só em sua romaria e que são muitos homens que também se chamam Severino, que nasceram de outras tantas Marias e estão indo rumo à morte. Reconstrói-se, assim, de forma muito sutil e imagética, o existencialismo e o universalismo que permeiam originalmente a obra de Melo-Neto, como podemos ver no trecho a seguir. 
Revista do Corpo Discente do Programa de Pós-Graduação em História da UnB EM TEMPO DE HISTÓRIAS | Brasília-DF | n. 37 | p. 473-493 | jul./dez. 2020.

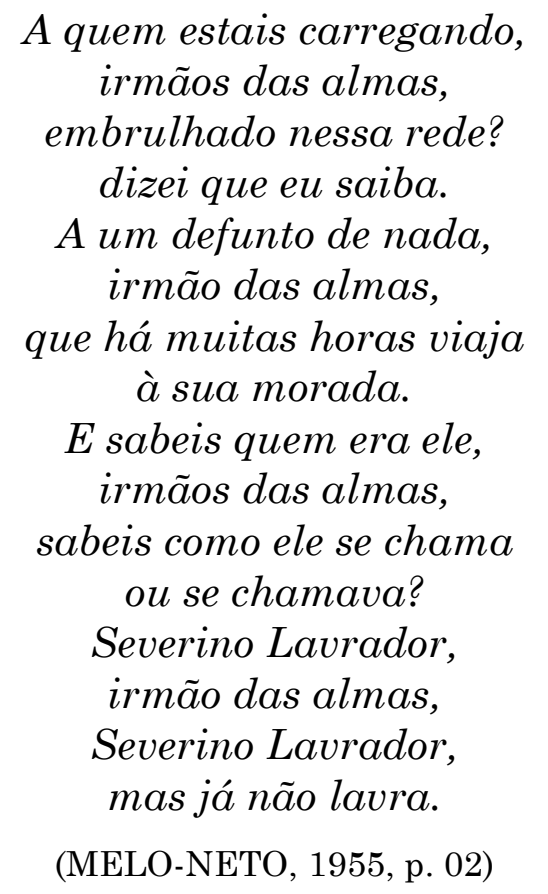

A cena acima é do segundo ato da peça-poema chamado "Encontra dois homens carregando um defunto numa rede, aos gritos de "Ó irmãos das almas! irmãos das almas! não fui eu quem matei não!" Nesse ato, a temática universalista se revela totalmente, sendo a morte o elemento que conecta todos os homens. Vemos que Serpa, com ajuda de Falcão, consegue recriar, graficamente, a temática da morte no sertão, assim como o existencialismo resultante dela. Esse processo ocorre, principalmente, por meio do uso das cores monocromáticas, em que o preto representa a morte e o branco o clarão do renascimento em um mundo de vazios, intenso e desnorteante. E, sobre esse aspecto da animação, Filipe Soares Branco da Costa Luz, em "O Movimento na Animação: Para uma Reclassificação Digital” (2013), lembra que “... na animação o desenho ou a cor tornam-se mais evidentes ... para tentar encaminhar o espectador para uma determinada emoção, com o auxílio da montagem, som ou representação dos actores" (COSTA-LUZ, 2013, p.148). Nesse sentido, na animação, o desenho de traços simples, ainda que seja a representação de um sertanejo, facilita a projeção da autoimagem do espectador nessa figura humana que, por sua vez, é mais uma representação universal da morte do que a de um homem específico.

De uma maneira inovadora, Serpa cria um universo monocromático em preto e branco a partir do existencialismo psicológico de Severino e uma imagem da morte projetada em seu rosto. Ao fazê-lo, Serpa parece querer deixar claro que não estamos no sertão físico de fato, senão na memória que o personagem-narrador tem da seca na sua terra natal. Não se trata de ver in loco a violência da seca que assola a natureza e as pessoas locais. Ao espectador, chegam apenas as impressões acústicas, psicológicas e emotivas da vivência de tantos Severinos nesse meio inóspito. Todas essas impressões aparecem sintetizadas em imagens que abstraem o sertão; é dizer, o transportam para o campo das ideias. Esse processo permite que a realidade transformada em animação 


\section{Historias}

Revista do Corpo Discente do Programa de Pós-Graduação em História da UnB EM TEMPO DE HISTÓRIAS | Brasília-DF | n. 37 | p. 473-493 | jul./dez. 2020.

ISSN 2316-1191

audiovisual, misturando técnicas cartunistas e de xilogravura, mergulhe o telespectador em uma narrativa universal sobre a relação do homem com sua existência.

São justamente essas estratégias audiovisuais minimalistas de Serpa que chamam a atenção dos telespectadores apreciadores da animação, da cultura e da história sertaneja. A animação tanto recupera como também destaca os traços mais essenciais do texto Morte e Vida Severina em que se inspirou. Ao falar do teatro essencialista, Davi Giordano em "O Teatro Essencial sob uma perspectiva minimalista" (2011), por meio da definição de Denise Stoklos das técnicas essencialistas, descreve esse tipo de estratégia como: "Um teatro que tem o mínimo possível de gestos, movimentos, palavras, guarda-roupa, cenário, acessórios e efeitos, mas que contém o máximo de poder dramático" (STOKLOS apud GIORDANO, 2011. p. 04). É isso o que acontece na animação Morte e Vida Severina que sintetiza, em imagens gráficas essenciais, o espaço físico do sertão, enquanto um universo absurdo, e que produz indivíduos como Severino. E, é exatamente nesses termos, de "um homem absurdo", com o rosto do espanto, que falamos de Severino a seguir.

O espanto do homem perante o mundo absurdo aparece na adaptação audiovisual da peça de Samuel Beckett chamada Waiting for Godot (1953) e em uma das cenas de Morte e Vida Severina. A cena do espanto na animação de Serpa deu origem ao cartaz de divulgação da obra. Buscou-se, assim, veicular justamente a expressão humana que determinou, em ordem cronológica, o tom narrativo da peça de Samuel Beckett e da adaptação audiovisual de Michael Lindsay-Hogg e, mais tarde, da animação Morte $e$ Vida Severina. Vejamos as Figuras 04 e 05 que representam esse contraste e atualização.

Figura 04: O Espanto e o Absurdo em Waiting for Godot

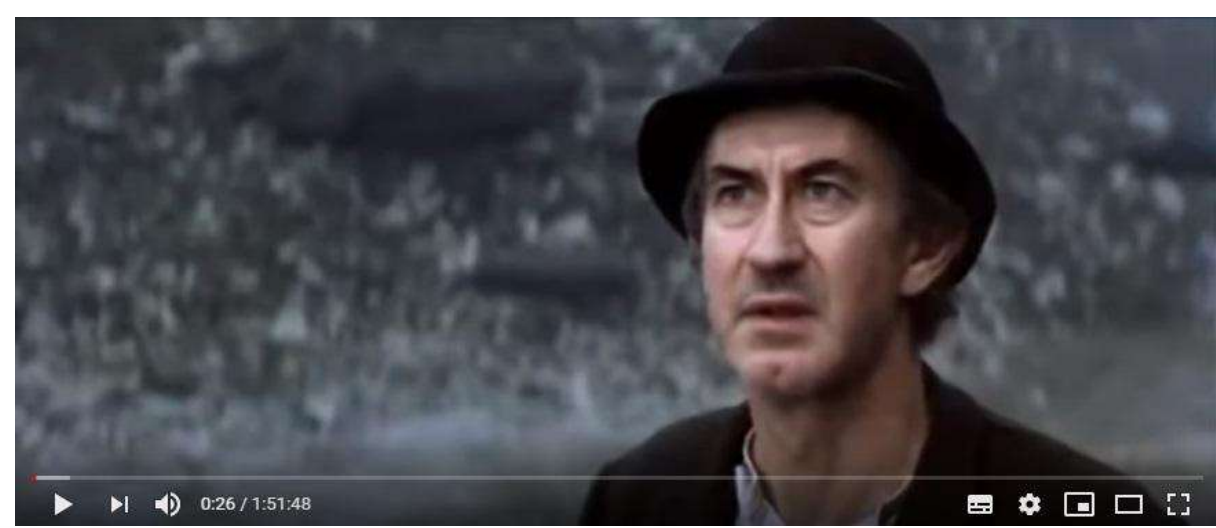

Fonte: Retirado de Lindsay-Hogg (2001, s. 26) 


\section{Historias}

Revista do Corpo Discente do Programa de Pós-Graduação em História da UnB EM TEMPO DE HISTÓRIAS | Brasília-DF | n. 37 | p. 473-493 | jul./dez. 2020.

ISSN 2316-1191

Figura 05: O Espanto e o Absurdo em Morte e Vida Severina

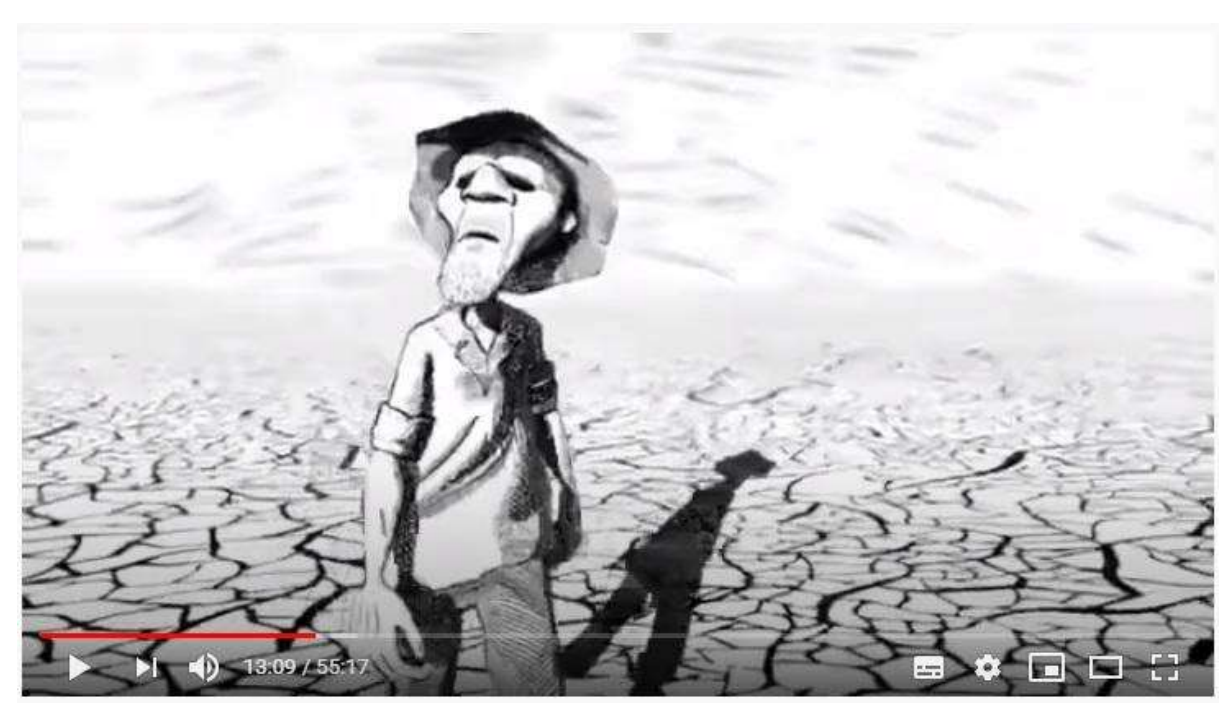

Fonte: Retirado de Serpa (2012, m. 13)

As Figuras 04 e 05 reconstroem o esquema de abstração do sujeito que foi mostrado por McCloud anteriormente na Figura 01, pelo qual acredito se dá a universalização das temáticas do homem moderno. Mas, se em McCloud olhávamos para a abstração de uma fotografia, nas Figuras 04 e 05, veremos a abstração da emoção humana capturada em vídeo. A face do espanto aparece primeiramente em um dos filme mais icônicos do Teatro do Absurdo, Waiting for Godot ${ }^{7}$, e depois se atualiza na animação de Serpa. Note-se que tudo ao redor se faz monocromático e monótono. O mundo parece se esvaziar em ambas cenas para dar destaque, em primeiro plano, à face do espanto. Esse esvaziamento cinematográfico, também chamado de minimalismo ou essencialismo, universaliza o existencialismo do homem moderno, respectivamente em um cenário do Pós-Segunda Guerra na Europa e depois na seca de 1919/1920 no Sertão Nordestino no Brasil, havendo uma atualização do universal no regional e vice versa.

Ao comparar Morte e Vida Severina com o Teatro do Absurdo na cena da peça de Beckett adaptada ao cinema, vemos que a temática do absurdo 8 é relevante tanto para a cinematografia mais universal, produzida na Europa, quanto para a cinematografia regional, produzida no Nordeste brasileiro. Esta última, como já definido anteriormente por Hayward, faz parte do Cinema propositadamente subdesenvolvido, o Third World Cinema, do qual a animação Morte e Vida Severina empresta as temáticas sociais da seca e da fome. Vemos, nas duas cenas acima, o espanto do homem frente ao vazio de

\footnotetext{
7 Para maiores detalhes, conferir a adaptação completa de Waiting for Godot por Michael Lindsay-Hogg (2001). Disponível em: <https://www.youtube.com/watch?v=izX5dIzI2RE>. Acesso em: 10 set. 2020.

${ }^{8}$ A temática do absurdo mostra o homem tentando entender a sua própria existência em um mundo vazio de sentido. Esse mundo trágico que foi primeiramente representado no Mito de Sísifo e depois no mundo Pós-Segunda Guerra agora se atualiza na seca do sertão nordestino. É possível que ele se atualize novamente na cinematografia pós 2020, no mundo pós-pandemia, por exemplo.
} 
Revista do Corpo Discente do Programa de Pós-Graduação em História da UnB EM TEMPO DE HISTÓRIAS | Brasília-DF | n. 37 | p. 473-493 | jul./dez. 2020.

um mundo hostil à sua existência e sua sanidade, e que faz dele o seu produto: o homem absurdo. A hostilidade está representada, na primeira cena, por meio da aridez do solo rachado, enquanto, na segunda cena, é percebida pelos escombros atrás de Vladimir. Conclui-se que o homem absurdo surge de situações limites, ou seja, da hostilidade da guerra, da seca, da fome, que acabam por marcar não apenas a estética das artes visuais que os introduzem no contexto universal, mas do próprio mundo em que vivem.

A tradição de retratar universos absurdos e hostis à existência humana surgiu ainda no Teatro da Grécia Antiga. O Mito de Sísifo, por exemplo, fala de um homem que repete diariamente a tarefa de rolar uma pedra até o topo de uma montanha e, como castigo, os Deuses fazem desta uma tarefa impossível: a pedra rolava montanha abaixo, matando-o pouco antes de alcançar o topo, o que força o homem a renascer e a recomeçar a tarefa que o levará novamente à morte. Esse mito se atualiza na animação Morte $e$ Vida Severina no Nordeste de Pernambuco, onde as personagens como Severino levam a cabo sua sina de retirantes em uma seca que não se acaba. Pelo contrário, quanto mais Severino avança na sequidão do sertão, mais se aproxima da morte. Mas a morte não será o fim, pois Severino nascerá novamente, como outro retirante, outro homem do pósguerra, outro Sísifo, para dar continuidade à jornada humana em uma peregrinação cíclica e absurda.

No seu ensaio filosófico de mesmo nome, O Mito de Sísifo de 1941, originalmente publicado em francês, o filósofo e dramaturgo franco-argelino, Albert Camus, elabora sua Filosofia do Absurdo pensada, exatamente, a partir da jornada humana em um mundo ininteligível e sem perspectiva. É possível que os caminhos percorridos por personagens do absurdo como Severino variem, podendo ser um cenário de um lugar devastado pela Segunda Guerra Mundial como no Teatro de Beckett, a subida de uma montanha como no Mito de Sísifo ou o caminho da seca no Nordeste do Brasil como em Morte e Vida Severina. Contudo, em todos esses mundos, há um pessimismo e uma resignação que produzem a agudeza existencial que ecoa em "somos, muitos Severino" e "Nothing to be done" (Nada a ser feito). Na arte que tem por matéria-prima o absurdo existencial, somos todos Severinos a caminho da morte e não há nada que se possa fazer.

O ciclo de Morte e Vida Severina começa já na abertura, onde vemos a vida dar início à morte e a morte dar início à vida. É possível perceber, no nível da metanarração, que a abertura se conecta ao final da animação com cenas que se organizam em mise en abyme. Colocadas lado a lado, vemos que a cena de abertura poderia vir antes ou depois da sequência com as três cenas de fechamento. Tudo parece terminar e começar com esse clarão inebriante que aparece e se dissipa no final, revelando o próprio começo da animação de narrativa cíclica. Na abertura, o clarão se abre como a cortina do teatro (ou da própria vida), expondo o olhar do público aos primeiros estímulos visuais do cenário, permitindo também distinguir nele qualquer figura humana com as quais vão se identificar. Vejamos, a seguir, como a imagem de abertura no minuto 1 dialoga com as últimas cenas da animação a partir do minutos 51, como podemos ver na Figura 06: 


\section{Historias}

Revista do Corpo Discente do Programa de Pós-Graduação em História da UnB EM TEMPO DE HISTÓRIAS | Brasília-DF | n. 37 | p. 473-493 | jul./dez. 2020.

ISSN 2316-1191

Figura 06: O Ciclo Morte e Vida Severina em Cor e Som
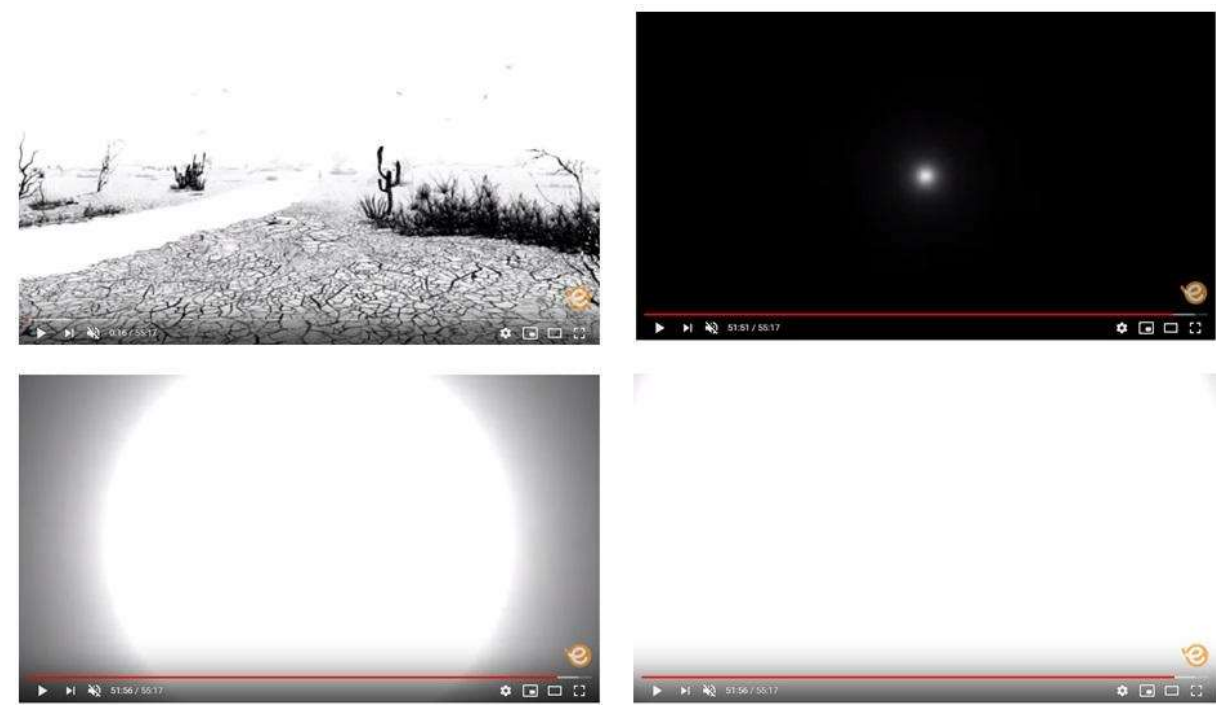

Fonte: Retirado de Serpa (2012, s.26 e seg)

Logo na primeira cena da animação Morte e Vida Severina, retratada no primeiro quadrante da Figura 06, deparamo-nos com um cena em que o "vazio" se dissipa no horizonte. Esse vazio é visualmente representado pela cor branca predominante na cena e também pela sonoridade. A sonoridade, nesse momento da narrativa, surge como um oxímoro, pois Serpa faz com que o silêncio ganhe sonoridade e apareça como trilha sonora, preenchendo o vazio existencial do mundo de Severino. O silêncio evolui de um "flat line sound" extradiegético para sons de órgão agudos diegéticos. O silêncio é reconstruído com o que parece ser o som de um sintetizador. O som é realmente ultraagudo, intenso e constante, alinhando-se ao vazio humano, agravando-o e tornando-o perturbador. É como se fosse um signo que representasse ou mesmo antecipasse a presença da morte no sertão. O som se torna parte da natureza na qual se insere Severino, especificamente quando se mistura e se confunde com o canto dos pássaros de agouro do sertão.

O nome Severino é responsável por estabelecer o tom universalista da peçapoema, pois é o nome dos que nascem e dos que morrem. O nome Severino sintetiza o que há de essencial no homem e que o conecta aos demais: a incapacidade de qualquer homem perante a morte. Quando o som agudo atinge seu ápice, preenchendo o vazio do sertão, nos vai sendo mostrado, ainda que de longe, uma pobre alma viajante, que remete à figura de um homem que já nasce condenado à morte: "só mais um severino" (MELO-NETO 1955 apud SERPA 2012). O personagem Severino que se materializou aos poucos, ainda na cena do primeiro quadrante da Figura 06, surge apenas para cumprir sua sina, ou seja, seu ciclo de vida e morte severina. Logo ele terá sua existência completamente apagada. O apagamento existencial começa no segundo quadrante da Figura 06, quando a cor preta se fecha como uma cortina fúnebre sobre sua vida. $\mathrm{O}$ apagamento é retomado no terceiro quadrante, na cor branca, e atinge seu auge, gradualmente, na última cena. Nessa cena surge o clarão que trará Severino de volta ao sertão. 


\section{Fistoriarias}

Revista do Corpo Discente do Programa de Pós-Graduação em História da UnB EM TEMPO DE HISTÓRIAS | Brasília-DF | n. 37 | p. 473-493 | jul./dez. 2020.

ISSN 2316-1191

Vemos que a narrativa começa e termina com o vazio que é representado visualmente, no quarto quadrante da Figura 06, pela predominância da cor branca. É nesse momento que nos damos conta de que a animação Morte e Vida Severina é uma obra cíclica, pois o clarão que predomina ao final é o mesmo que se dissipa ao começo. Isto é dizer que, após a morte de (um) Severino, marcado pela predominância da cor preta, no segundo quadrante da Figura 06, vemos que a vida ressurge no centro da cena como um ponto de luz branca. Esse ponto de luz vai se expandindo até os limites da tela e, ao atingir seu ápice, o clarão inebriante começa a se esvair, entregando ao mundo (mais um/outro) Severino. Esse Severino é recebido pelo som do silêncio no início da animação, um som agudo e incômodo que o entrega ao vazio de sua existência. Estamos diante de uma trama circular que encerra a sina de vida e morte de tantos Severinos. Assim se inicia a romaria humana, de agudeza constante, e que acompanha o homem desde seu surgimento no mundo até a sua morte, como é mostrado na Figura 07:

Figura 07: Ato II - Encontra Dois Homens Carregando Um Defunto Numa Rede, Aos Gritos De “Ó Irmãos Das Almas!”

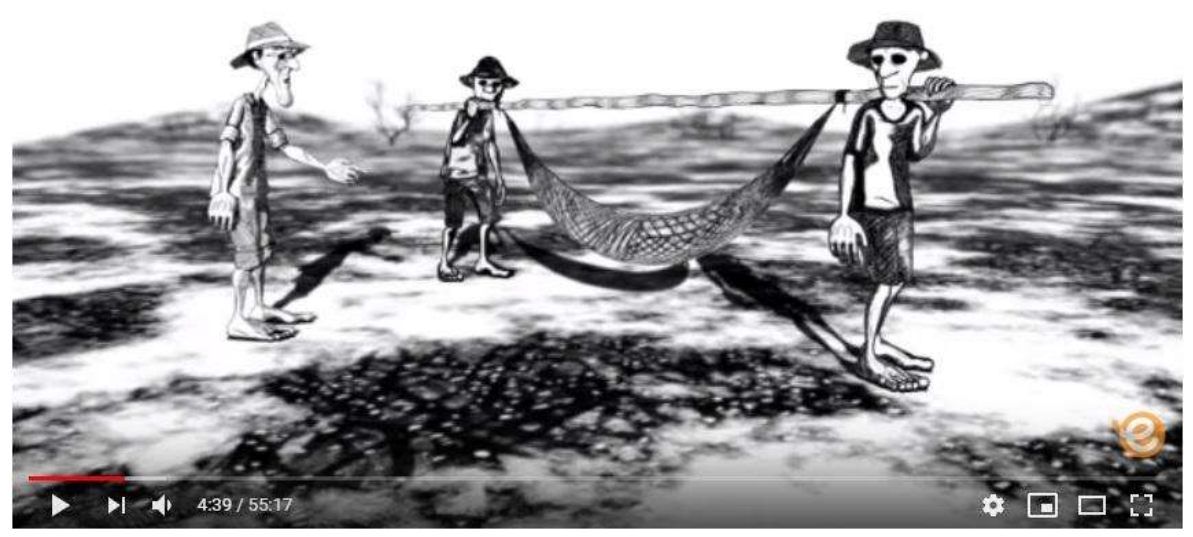

Fonte: Retirado de Serpa (2012, m4., s. 39)

A cena acima foi pensada para condensar, na repetição de imagens, a universalidade de uma existência humana efêmera. Os personagens compartilham, exatamente, o mesmo rosto sem vida e seus olhos são reflexo da natureza morta que os cercam. Essa técnica de representação minimalista catalisa o poder dramático do qual se projeta o universalismo das temáticas humanas tratadas na peça-poema. $\mathrm{O}$ homem carrega a si mesmo para a morte. Enquanto alguns caminham em vida, outros já viajam a horas rumo à última morada - algum lugar entre a escuridão da morte e o clarão do nascimento. Se algum dia o homem que morreu tivesse sido mais que um Severino, talvez um lavrador, isso já não importava mais. A morte fez dele só mais um Severino que "já não lavra". 


\section{Fistortias}

Revista do Corpo Discente do Programa de Pós-Graduação em História da UnB EM TEMPO DE HISTÓRIAS | Brasília-DF | n. 37 | p. 473-493 | jul./dez. 2020.

ISSN 2316-1191

É assim que nasce(m) Severino(s): da morte que preenche o vazio do sertão e também o mundo. E, é através da morte que Severino(s) se conecta(m) ao resto da humanidade. A morte e o renascimento são as únicas certezas de tantos Severinos. Como falamos anteriormente, são homens que nascem sentenciados a serem muitos e iguais em tudo na vida, filhos da mesma mãe morte, uma mãe tão universal quanto o seu nome na peça-poema, Maria. Esta foi a interpretação de um dos trechos da peça-poema que foi retirado da estrofe de abertura que termina com os seguintes versos: "morremos de morte igual/ mesma morte Severina (MELO-NETO, 1955, p. 01). Eis aí a universalidade da peça-poema e da animação: tratar da condição de homens (ou personagens) diferentes fadados a compartilhar a mesma máscara de espanto diante do ciclo cruel da vida e da morte que são partes inerentes à jornada humana que nunca termina.

A Figura 08 sintetiza bem o significado do título e, consequentemente, a essência da animação Morte e Vida Severina, enfatizando também sua ciclicidade narrativa.

Figura 08: O Ciclo da Morte e Vida Severina
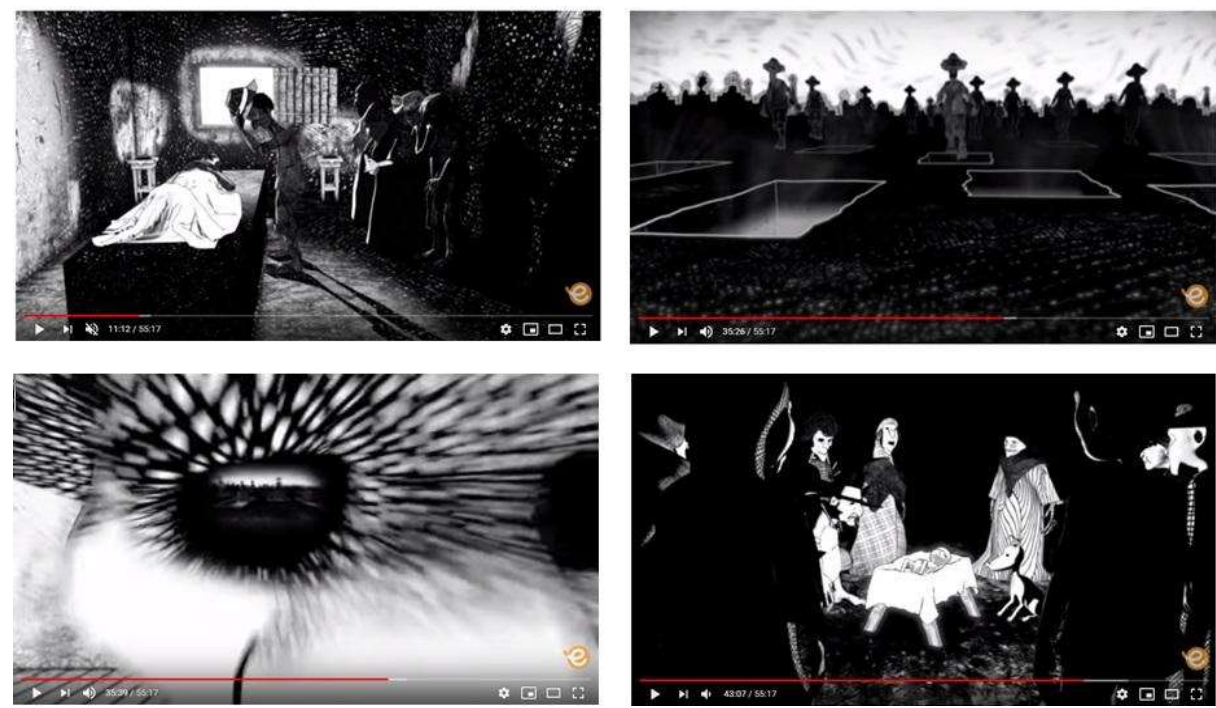

Fonte: Retirado de Serpa (2012, m. 11, s.13)

Nessa narrativa, a morte e o nascimento são um contínuo, fases da mesma romaria existencial e não se distinguem em Morte e Vida Severina. Em outras palavras, viver não é melhor do que morrer e nem morrer é melhor do que viver. Na segunda, terceira e quarta imagem, vemos que a morte é algo internalizado pelo homem ainda no berço e o acompanha ao seu leito de morte. Descobrimos também que o agouro, sobre o qual falamos há pouco, anuncia o fim da vida de um indivíduo, mas a saga humana, do homem universal, continuará com outro(s) indivíduo(s). Vemos, na primeira foto da seleção acima, que o corpo que Severino carregava chegou à casa onde será velado. Lá, o Severino Lavrador, que na morte voltou a ser apenas mais um Severino, começa outra jornada até o que ele esperançosamente pensa ser sua última morada. Mas, como prova a cena do último quadrante da Figura 08, ele está fadado a renascer para continuar sua sina. 


\section{Fistororias}

Revista do Corpo Discente do Programa de Pós-Graduação em História da UnB EM TEMPO DE HISTÓRIAS | Brasília-DF | n. 37 | p. 473-493 | jul./dez. 2020.

ISSN 2316-1191

No quarto ato da peça-poema, todos se encontram na casa do defunto. Todos estão cantando excelências para o defunto. A multidão parece guiar a pobre alma por meio de orações uníssonas e ritmadas, como mostra o trecho abaixo retirado do poema Morte $e$ Vida Severina escrito por Melo-Neto (1955, p. 07):

- Finado Severino,

quando passares em Jordão

e o demônios te atalharem

perguntando o que é que levas...

- Dize que levas cera, capuz e cordão

mais a Virgem da Conceição.

- Finado Severino, etc...

- Dize que levas somente coisas de não:

fome, sede, privação.

- Finado Severino, etc...

- Dize que coisas de não, ocas, leves:

como o caixão, que ainda deves.

- Uma excelência

dizendo que a hora é hora.

- Ajunta os carregadores

que o corpo quer ir embora.

- Duas excelências...

-...dizendo é a hora da plantação.

- Ajunta os carregadores...

-...que a terra vai colher a mão.

(MELO-NETO, 1955, p. 7)

A oração em jogral é comum em Autos de Natal, que é um gênero tradicional no Nordeste. A escolha pelo jogral faz com que a narrativa ganhe tom litúrgico e soe como uma oração mística (i.e. casting a spell). O corpo agora desalmado e velado tem vontade de ir embora. A peça-poema diz que "é hora da plantação" e, nessa hora, Severino Lavrador volta a adubar a terra com seus próprios restos mortais. A terra colhe seu corpo a mão para fortalecer o chão seco que será a penitência de outro Severino. Assim morre o lavrador Severino que tanta terra lavrou. Vemos, na segunda imagem, que ele apenas cumpre a sina de tantos outros Severinos que, mesmo em vida, já carregavam a morte no vazio dos olhos. São muitos os homens que (re)nascem para continuar a romaria universal que, neste trabalho, foi chamada de Morte e Vida Severina. Mas, seja com Sísifo na Grécia Antiga, com Vladimir (em Waiting for Godot) ou com Severino no sertão — não importa o nome do "homem absurdo" —, a saga humana continua. 


\section{Fistororias}

Revista do Corpo Discente do Programa de Pós-Graduação em História da UnB EM TEMPO DE HISTÓRIAS | Brasília-DF | n. 37 | p. 473-493 | jul./dez. 2020.

ISSN 2316-1191

Como um último comentário que relaciona Morte e Vida Severina ao Mito de Sísifo, vale notar que o prefácio do livro de Camus em português, O Mito de Sísifo: ensaio sobre o absurdo (1954), encontrado na biblioteca digital da PUC-campinas, define o livro como um "livro de terrível beleza com a sua aguda apreensão do horror nas armadilhas do cotidiano, seu reforço ao inconformismo e à recusa a todas as fugas, seu empenho intransigente em valorizar e enriquecer as lutas da lucidez" (CAMUS, 1954, p. 2). Sem muito esforço, constatamos que poderíamos aplicar a mesma descrição à animação Morte e Vida Severina, pois ela traz uma narrativa em que a lucidez se perde na atmosfera de agouros, no vazio do cotidiano e na apreensão de um mundo absurdo e seus horrores.

No que tange à conexão de Morte e Vida Severina com o Teatro mais universal, vale a pena mencionar aqui a descrição de Martin Esslin da "Estética do Absurdo", já que vimos exemplos na animação: "O Teatro do Absurdo se esforça para expressar uma condição humana de dormência e a inadequação da abordagem racional motivada pelo abandono de dispositivos racionais e do pensamento discursivo"9 (ESSLIN 1961 apud GUSSOW 2002, p. 25). A descrição de Esslin, professor e um dos autores do Teatro do Absurdo, foi retomada em nota publicada no The New York Times em 5 de junho de 2002 por ocasião da sua morte. Basicamente, o que se pode apreender é que se trata de um tipo de narrativa cênica que se especializou em colocar em cena não o mundo em si (i.e. o sertão físico), mas as impressões deixadas por esse mundo "absurdo" no psicológico humano. É justamente isso que vimos em Morte e Vida Severina, em que a atmosfera de morte do sertão impregna o psicológico e a própria existência do personagem Severino.

No tocante às técnicas minimalistas presentes na animação de Serpa, averiguamos que elas ocorreram pela sintetização de significados essenciais. E, nesse contexto, Fernando Mesquita em "O máximo com o mínimo: a cena minimalista de Samuel Beckett" (2011), fala de Samuel Beckett nos mesmos termos que venho utilizando para descrever a arte de Serpa. Ele lembra que: "Beckett se apropriava do 'mínimo' para dizer o máximo, servindo-se de alguns recursos para induzir o seu público a compreender ... o tom abstrato, o uso de cores monocromática, o uso do silêncio; a utilização das repetições de palavras, frases e imagens" (MESQUITA, 2011, p. 02). Essa técnica descrita por Mesquita é catalisadora da universalização de significados e pôde ser identificada também no trabalho de Serpa. Por isso, o enfoque deste estudo esteve sempre nos detalhes, no mínimo, no que parecia ser banal, mas que foi ampliado de forma intencional e sistemática na mise-en-scéne de Morte e Vida Severina. Vemos, assim, o mínimo de Mesquita, resultado da convergência do uso de formas mais neutras, de imagens mais abstratas, das cores monocromáticas, etc., se atualizar no máximo, no todo da animação, de Serpa. À vista disso, surge uma cinematografia do espanto, do vazio, do espaço psicológico afetado pelo desconhecido; ou seja, elementos que transformam Severinos em homens absurdos e universais.

\footnotetext{
9 Tradução nossa. O original diz: "The Theater of the Absurd strives to express its sense of the senselessness of the human condition and the inadequacy of the rational approach by the open abandonment of rational devices and discursive thought" (ESSLIN 1961 apud GUSSOW 2002, p. 25).
} 


\section{Hilstortorias}

Revista do Corpo Discente do Programa de Pós-Graduação em História da UnB EM TEMPO DE HISTÓRIAS | Brasília-DF | n. 37 | p. 473-493 | jul./dez. 2020.

ISSN 2316-1191

\section{Considerações finais}

Neste trabalho, analisei a adaptação da peça-poema Morte e Vida Severina como um exemplo cinematográfico que conecta o regional e o universal. O foco da análise foi verificar como a proposta de uma cinematografia cartunista de Serpa ajudou a atribuir significados universais a uma narrativa histórica do Nordeste brasileiro. Em seguida, buscamos entender como Serpa recuperou os significados do texto original, contidos na peça-poema de Melo-Neto, através de técnicas cinematográficas e cartunistas; e os amplificou no minimalismo visual da sua animação. Na sequência, analisamos como a estética cinematográfica e os objetivos de Serpa trabalhados na animação dialogavam com as artes audiovisuais (i.e. Cinema) do Terceiro Mundo.

Primeiramente, verificamos que os elementos que aparecem enfatizados na animação de Serpa, muitas vezes, não eram nem mesmo algo físico ou visível, mas uma sensação ou sentimento sutil ou um elemento abstrato metaforizado. Por exemplo, o silêncio que é trabalhado através de sons agudos e que preenche a atmosfera cênica, encaminha o espectador a notar o vazio existencial e a presença da morte no sertão. Constatamos ainda que as cores monocromáticas dão à narrativa tons mais abstratos e condizentes com o espaço psicológico de Severino enquanto "Homem Absurdo". Nesse espaço, a repetição de imagens, do mesmo rosto de espanto nos vários Severinos, dão conta da universalização da temática da morte. Por sua vez, a universalização é possível porque Serpa explora a representação da morte ainda no campo das ideias e das impressões mentais que são universais. Ele prioriza o que originalmente estava sobreposto pela linguagem escrita da peça-poema, ou seja, os conceitos e abstrações ainda não codificados. Tem-se, assim, a facilitação da assimilação dos conceitos abstratos (i.e. a percepção da morte) em Morte e Vida Severina.

Ainda relacionado à percepção da morte, foi possível averiguar que a animação Morte e Vida Severina deixa evidente que as temáticas do sertão, enquanto espaço predatório à existência do sertanejo, são também reflexos de outras realidade mais universais e de outros mundos absurdos, sejam eles míticos ou reais (i.e. Mundo PósSegunda Guerra). No final, atestamos que o mundo preto e branco, o som agudo do vazio humano e a falta de perspectiva da existência humana em um mundo absurdo ficam impressos também no espectador e sua visão de mundo. Assim, Severino tem sua visão afetada de mundo compartilhada através da animação. Talvez, até o espectador se dê conta de que também é só mais um "homem universal," um Severino vivendo sua jornada sisífica nesse mundo de absurdos; vivendo, constantemente, na ciclicidade de realidades pós-guerra/pós conflitos.

Como contribuição para o Cinema brasileiro, tem-se a recuperação de uma estética revolucionária que imprime sofisticação no que foi um dos episódios mais duros da história do Nordeste brasileiro, a seca de 1919/1920. Ao misturar a xilogravura monocromática e cartunismo, enfatizam-se as possibilidades de um cinema regional e minimalista na abordagem de temas universais. Nesse sentido, Serpa fez uma animação $3 \mathrm{D}$ que, mesmo consciente das muitas possibilidades cinematográficas, ateve-se ao essencial, ao mínimo, às percepções mais sutis da seca no sertão e da realidade de 
Revista do Corpo Discente do Programa de Pós-Graduação em História da UnB EM TEMPO DE HISTÓRIAS | Brasília-DF | n. 37 | p. 473-493 | jul./dez. 2020.

Severino; e, a partir disso, conseguiu fazer interseções com o universal. É notório ainda a preocupação de Serpa com o engajamento político tão característico da cinematografia dita do Terceiro Mundo, como é o caso do Cinema Novo. A obra de Serpa estabelece o diálogo com o público ao se ocupar da universalização da narrativa de Morte e Vida Severina e da realidade da seca pelo público. Com isso, Serpa mostra os impactos da seca do sertão para o mundo, mas deixa a interpretação e crítica social à cargo diretamente do público. Nesse sentido, ao optar pelo minimalismo, Serpa evitou que a superutilização da criatividade autoral se sobrepusesse, desnecessariamente, à história contada.

Por fim, é possível dizer que as impressões psicológicas do sertão, enquanto universo absurdo de Morte e Vida Severina, parecem se revelar diretamente ao público por meio de efeitos sonoros e cores monocromáticas utilizados de forma precisa na criação da atmosfera de morte no sertão. Serpa consegue, assim, despertar a empatia de um público mais universal por uma tragédia histórica regional, a seca no sertão. Dessa forma, verificamos que a animação Morte e Vida Severina mostra que a arte visual mais sofisticada nem sempre carrega a estética mais adornada. Pelo contrário, procura-se traduzir o máximo com o mínimo, potencializando significados que são inerentes à realidade representada, mas que podem ser também universalizados.

\section{Referências}

CAMUS, Albert. $O$ mito de Sísifo: ensaio sobre o absurdo com um estudo sobre Franz Kafka. Tradução de Urbano Tavares Rodrigues e Ana de Freitas. Lisboa: Edição Livros do Brasil, 1954, $173 \mathrm{p}$.

COSTA-LUIZ, Filipe. O Movimento na Animação: Para uma Reclassificação Digital. 2013. 439f. Tese (Doutorado em Ciências da Comunicação) - Programa de PósGraduação em Ciências da Comunicação, Universidade Nova de Lisboa, Lisboa, 2013. Disponível em: <http://hdl.handle.net/10362/12101>. Acesso em: 10 set. 2020.

GIORDANO, Davi. O Teatro Essencial sob uma perspectiva minimalista. Revista Lindes, n. 2, 2011. p. 1-22. Disponível em: <https://bit.ly/2RaHtSv>. Acesso em: 10 set. 2020.

GUSSOW, Mel. Martin Esslin, Drama Theorist, Dies at 83. The New York Times, 2002, p. 55. Disponível em: <https://www.nytimes.com/2002/06/05/arts/martin-esslin-dramatheorist-dies-at-83.html>. Acesso em: 10 set. 2020.

HAYWARD, Susan. Cinema Studies: The Key Concepts. London: Editoral Routledge, 2000. p. 576

LAFALCE, Luiz Camilo. Breve Comentário sobre o Teatro do Absurdo. Revista Pandora Brasil, n. 31, 2011, p. 1-9. Disponível em:<http://revistapandorabrasil.com/>. Acesso em: 24 out. 2020.

LINDSAY-HOGG, Michael. Waiting for Godot. Irlanda: Gate Theatre Dublin/Blue Angel Films, 2001. 


\section{Filstorias}

Revista do Corpo Discente do Programa de Pós-Graduação em História da UnB EM TEMPO DE HISTÓRIAS | Brasília-DF | n. 37 | p. 473-493 | jul./dez. 2020.

ISSN 2316-1191

MELO-NETO, João Cabral. Morte e Vida Severina e Outros Poemas. Rio de Janeiro: Objetiva, 1955-2009.

MESQUITA, Fernando. O máximo com o mínimo: a cena minimalista de Samuel Beckett. Anais do XII Congresso Internacional da ABRALIC, v. 12, 2011, p. 317-326. Disponível em: <https://literatura.posgrad.ufsc.br/files/2012/08/Anais-eletrônico-ISimpósio-dos-Alunos-do-PGl-2011.pdf\#page=322>. Acesso em: 10 set. 2020.

MCCLOUD, Scott. Understanding Comics: The Invisible Art. New York: Edição Harper Perennial, 1994. p. 224.

SERPA, Afonso. Morte e Vida Severina: Animação. 2012. (55min18s). Disponível em $<$ https://www.youtube.com/watch?v=clKnAG2Ygyw>. Acesso em: 10 set. 2020.

YU, Jingfang. Da palavra à imagem: Morte e vida severina em animação. Revista Translation, n. 6, 2013, p. 31-39. Disponível em: $<$ https://www.seer.ufrgs.br/translatio/article/view/44666/28364>. Acesso em: 10 set. 2020 . 